\title{
PHARMACOGNOSTICAL STANDARDIZATION AND HIGH-PERFORMANCE THIN-LAYER CHROMATOGRAPHY FINGERPRINT OF ROOTS OF ANTHOCEPHALUS CADAMBA
}

\author{
KAVERIPAKAM SAISRUTHI*, ADIKAY SREEDEVI
}

Division of Pharmaceutical Chemistry, Institute of Pharmaceutical Technology, Sri Padmavati Mahila Visvavidyalayam (Women's University), Tirupati, Andhra Pradesh, India. Email: sruthisai7@gmail.com

Received: 23 April 2019, Revised and Accepted: 23 May 2019

\section{ABSTRACT}

Objective: Anthocephalus cadamba is a traditional medicinal plant which is valued for its benefits in the management of various ailments. The current study was aimed to provide requisite pharmacognostic details and high-performance thin-layer chromatography (HPTLC) fingerprint profile for the roots of A. cadamba.

Methods: Pharmacognostic evaluation included examination of morphological and microscopic characters, physicochemical analysis, fluorescence study, preliminary phytochemical analysis, and HPTLC fingerprint.

Results: The microscopic studies showed the presence of thick periderm, cortical zone, secondary phloem, and secondary xylem. Microscopic examination of root powder showed abundant fibers and vessel elements. The physicochemical analysis of root powder helped in the assessment of quality control parameters. Fluorescence analysis of root powder imparted characteristic colors on the treatment of the powder with different reagents. Preliminary phytochemical studies reported the presence of alkaloids, saponins, flavonoids, steroids, terpenoids, glycosides, tannins, and other phenolic compounds. The developed qualitative densitometric HPTLC fingerprint can be used as an identifying biochemical marker for ethanol extract of the roots of $A$. cadamba.

Conclusion: The present study provides the information with respect to identification and authentication of crude drug and serves as a reference point for the proper identification of roots of this medicinal plant, thereby contributing to the scientific world of research.

Keywords: Anthocephalus cadamba, Pharmacognostic, High-performance thin-layer chromatography, Fluorescence.

(C) 2019 The Authors. Published by Innovare Academic Sciences Pvt Ltd. This is an open access article under the CC BY license (http://creativecommons. org/licenses/by/4. 0/) DOI: http://dx.doi.org/10.22159/ajpcr.2019.v12i7.33658

\section{INTRODUCTION}

Medicinal plants play an active role in traditional medicines for the treatment of various diseases. However, the key obstacle, which hindered the promotion in the use of traditional medicines in the modern society, was no evidence of documentation and absence of stringent quality control measures [1]. Hence, there is dire need to make sure about the standardization of the plant and parts of the plant to be used as a medicine. From the past few years, implementation of new good manufacturing practices in quality control of raw materials, intermediates, and finished products of botanical origin was taken place [2]. Correct characterization and quality assurance of starting material are an essential step to ensure reproducible quality of herbal medicine which will help us to justify its safety and efficacy [3].

Anthocephalus cadamba (F: Rubiaceae) is a traditional medicinal plant which is valued for its benefits in the management of various ailments. It is native to South Asia which was used traditionally to treat various ailments such as ophthalmic infections, cutaneous diseases, dyspepsia, gum related problems, stomatitis, cough, fever, hematological, and urinary disorders [4]. As the plant shows different pharmacological activities, but till date, there were no reports on pharmacognostic studies and high-performance thin-layer chromatography (HPTLC), this study is inevitable. Hence, the current study is focused to study the pharmacognostic parameters such as microscopic, physicochemical, fluorescence studies, preliminary phytochemical screening, and HPTLC analysis of the roots of A. cadamba.

\section{MATERIALS AND METHODS}

Collection and authentication of plant material

The roots of $A$. cadamba were collected from Tirumala hills and authenticated by Botanist Dr. Madhavachetty. A specimen (No. 1856) was deposited in herbarium at Sri Venkateswara University, Tirupati, India. Roots were initially washed, shade dried, and ground in Wiley mill.

\section{Macroscopic studies}

The roots were subjected to macroscopic studies which comprised organoleptic characteristics such as color, odor, appearance, and texture of the drug. These parameters were evaluated as per the standard WHO guidelines [5].

\section{Microscopic studies}

Microscopic studies were carried as per the methods of Sass, 1940, Brain et al., 1975, Johansen, 1940, and Easu, 1964 [6-9]. The required samples were cut and removed from the plant and fixed in FAA (Formalin - $5 \mathrm{ml}+$ Acetic acid $-5 \mathrm{ml}+70 \%$ Ethyl alcohol $-90 \mathrm{ml}$ ). After $24 \mathrm{~h}$ of fixing, the specimens were dehydrated with graded series of tertiary-Butyl alcohol [6]. Infiltration of the specimens was carried by gradual addition of paraffin wax (melting point $58-60^{\circ} \mathrm{C}$ ) until TBA solution attained supersaturation. The specimens were cast into paraffin blocks [7].

\section{Sectioning and staining}

The paraffin-embedded specimens were sectioned with the thickness of the sections $10-12 \mu \mathrm{m}$ by the help of rotary microtome. The dewaxing of the sections was done by customary procedure [7]. The sections were stained with Toluidine blue [10]. Wherever necessary, sections were also stained with safranin, fast green, and iodine-potassium iodide.

\section{Photomicrographs}

All permanent slides after staining were dehydrated using graded series of ethanol + xylol and mounted in DPX. Photographs of different magnifications were taken with Nikon Labophot 2 microscopic unit. For 
normal observations, bright field was used. For the study of crystals, starch grains, and lignified cells, polarized light was employed. Since these structures have birefringent property, under polarized light, they appear bright against dark background. Magnifications of the figures are indicated by the scale bars. Descriptive terms of the anatomical features are as given in the standard Anatomy books [9].

\section{Powder microscopy}

To study the presence or absence of various types of tissues or structures, the dried root is powdered using electric grinder, passed through sieve No. 60, and then subjected for microscopic studies $[11,12]$.

\section{Physicochemical analysis}

Physicochemical parameters such as total ash value, acid-insoluble ash value, water-soluble ash value, $\mathrm{pH}$, moisture content, and extractive values were determined using crude powdered drug of roots as per the WHO guidelines [13].

\section{Fluorescence analysis}

Small amount of powdered drug about $1 \mathrm{~g}$ is taken in a Petri dish and treated with different chemical reagents. The fluorescence character of the drug was studied by observing under daylight and ultraviolet (UV) light [14].

\section{Preparation of extract}

The root powder was defatted with petroleum ether $\left(60-80^{\circ} \mathrm{C}\right)$. The defatted marc was air-dried and macerated with ethanol for $24 \mathrm{~h}$. Macerated material was refluxed for $3 \mathrm{~h}$ and then filtered. The procedure was repeated twice and obtained filtrate was combined and subjected to distillation under reduced pressure.

\section{Preliminary phytochemical studies}

Petroleum ether and ethanol extract of A. cadamba was subjected to preliminary phytochemical studies by employing standard methods to detect the presence of various phytoconstituents [15].

\section{HPTLC}

A densitometric HPTLC analysis was carried for the development of characteristic HPTLC fingerprinting profile. Ethanol extract of roots was dissolved in methanol and used as a test solution for HPTLC analysis. A $4 \mu \mathrm{L}$ aliquot of test solution was loaded on $5 \mathrm{~cm} \times 10 \mathrm{~cm}$. Aluminum packed TLC plate coated with $0.2 \mathrm{~mm}$ layer of silica gel $60 \mathrm{~F}_{254}$ (E. Merck Ltd., Darmstadt, Germany) stored in a desiccator. Hamilton microsyringe (Switzerland) mounted on a Linomat $\mathrm{V}$ applicator was used for application. Spotting was done on the TLC plate and the plate was kept in TLC twin trough developing chamber allowing ascending development of the plate with the migration distance $80 \mathrm{~mm}$ (distance to the lower edge was $10 \mathrm{~mm}$ ) which was carried out at $22^{\circ} \mathrm{C}$ in a Camag chamber previously saturated for $30 \mathrm{~min}$. The mobile phase used is toluene:ethyl acetate:methanol (1:8:1). After development, the plate was subjected to dry by hot air oven for $5 \mathrm{~min}$. Then, densitometric scanning was done with a Camag TLC Scanner 3 equipped with win CATS Software and the chromatograms were recorded.

\section{RESULTS}

\section{Macroscopic studies}

The root was outer dark brown and inner creamy in color. They were characteristic in odor and slightly bitter in taste. Outer surface of the root is firm, rough, and striated and inner side is soft.

\section{Microscopic studies}

The thin root is about $1.3 \mathrm{~mm}$ and the thick one is about $3 \mathrm{~mm}$ in diameter. Root consists of thick periderm, cortical zone, secondary phloem, and secondary xylem. The root has uniformly thick continuous periderm cylinder extending all around the circumference. The periderm consists of homogeneous squarish thin-walled cells, the cells are in regular radial rows. In the middle part of periderm, there present two layers of lignified cells called phelloids. The remaining periderm tissue includes about many layers of thin-walled suberized cells called phellem cells.
Inner to the periderm is the cortical zone comprising about six layers of cells. The cortical cells include parenchyma cells and fibers. The parenchyma cells are elliptical, compact, and thin walled. Some of them have mucilage inclusions. The fibers are solitary or in small cluster of two or three cells which are scattered in the cortical zone.

Secondary phloem occurs as a continuous cylinder along the outer part of the secondary xylem. The phloem parenchyma elements are squarish in shape and occur in compact radial rows. The sieve elements are in small circular clusters. Secondary xylem cylinder is wide, dense, and solid, measuring $3.4 \mathrm{~mm}$ in diameter. It includes vessel elements, xylem fibers, and dilated xylem rays. The vessels are long radial, angular in outline and are in multiples ranges from four to eight with diameter 30-70 $\mu \mathrm{m}$. Xylem fibers are narrow in sectional outline, polygonal and have thick lignified walls. Xylem rays are distinct, radially oblong, darkly stained, and thin-walled cells (Fig. 1)

\section{Powder microscopy}

Microscopic examination of root powder evidenced abundant fibers and vessel elements. Two types of fibers, namely wide fibers (up to $30 \mu \mathrm{m}$ wide and $750 \mu \mathrm{m}$ long) and narrow fibers (about $10 \mu \mathrm{m}$ thick and $450 \mu \mathrm{m}$ long) were observed. Wide fibers have thin walls, side lumen, and tertiary spiral thickenings. Most of these fibers have multiseriate slit like simple pits. Narrow fibers are but less abundant compared to wide fibers. Their walls are thick and slit-like pits are seen on the lateral walls of the fibers. Vessel elements are long, narrow, and cylindrical and are common. Some of them have long, narrow, tapering tails at the ends. At the end walls, wide circular perforations occurred and the lateral walls are dense and multisclerotic (Fig. 2).

\section{Physicochemical analysis}

The physicochemical analysis helped in the assessment of quality control parameters. Various physicochemical parameters were assessed and the identified results are mentioned in Table 1.

\section{Fluorescence analysis}

Fluorescence analysis of root powder imparted characteristic colors on the treatment of the powder with various reagents when observed under visible and UV light (Table 2).

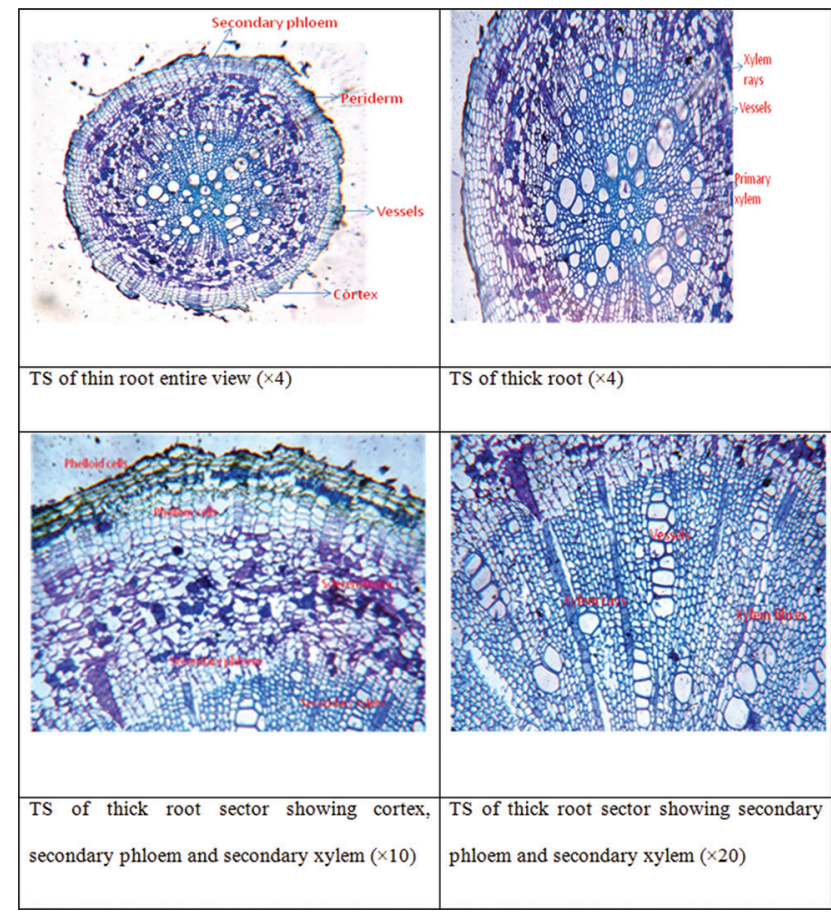

Fig. 1: Microscopic examination of the roots of Anthocephalus cadamba 


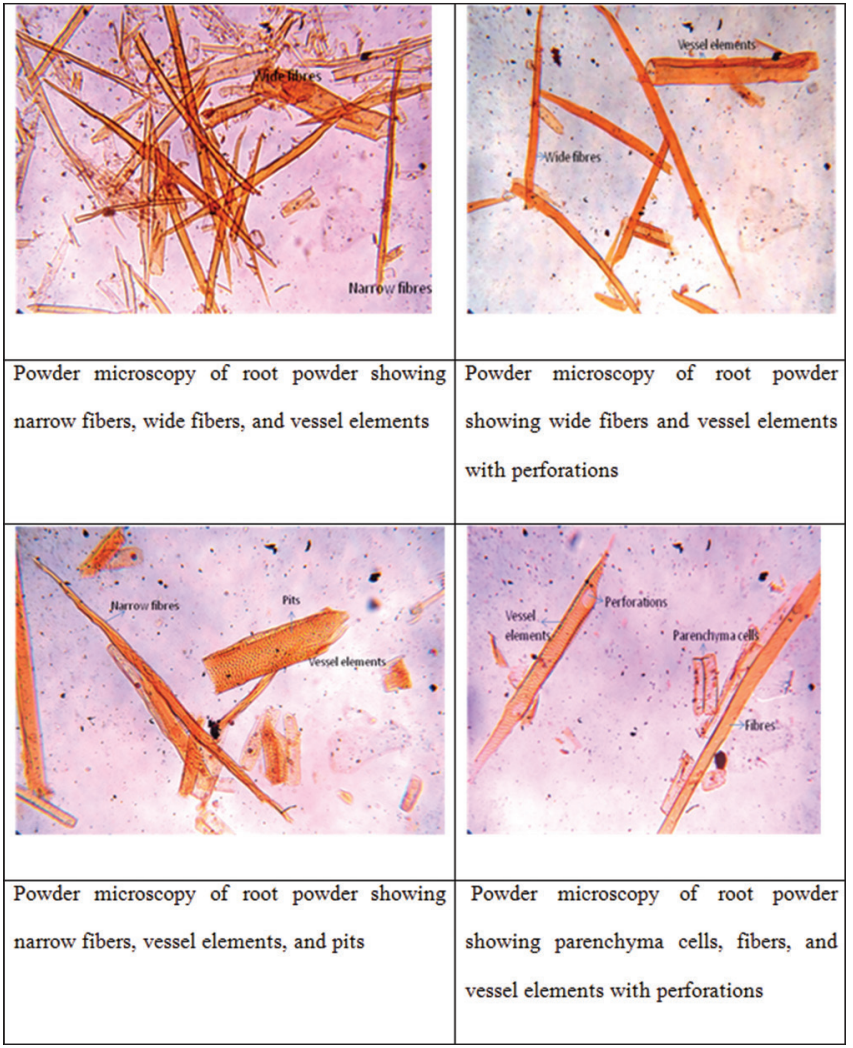

Fig. 2: Powder microscopy of the roots of A. cadamba

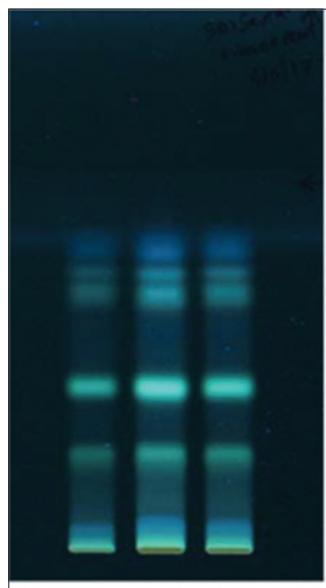

$366 \mathrm{~nm}$

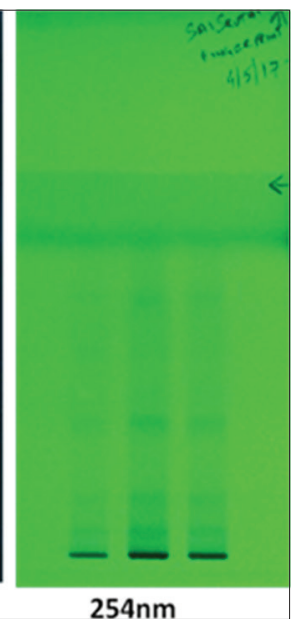

Fig. 3: High-performance thin-layer chromatography fingerprint analysis of ethanol extract of the roots of $A$. cadamba

Preliminary phytochemical screening

The petroleum ether and ethanol extract of the roots of $A$. cadamba showed in Table 3.

\section{HPTLC analysis of the roots of $A$. cadamba}

HPTLC analysis of ethanol extract showed the presence of seven phytoconstituents. The corresponding ascending order of $R_{f}$ values starts from -0.03 to 0.70 , in which the highest concentration of phytoconstituents was found to be $50.58 \%$ and its corresponding $R_{f}$ value was found to be 0.35 , respectively (Table 4 and Figs. 3,4 ).

\section{DISCUSSION}

Standardization of the herbal medicine is necessary to assure the quality, efficacy, and safety of the drugs [16]. The primary step in
Table 1: Physicochemical parameters of roots of Anthocephalus cadamba

\begin{tabular}{lll}
\hline S. No. & Parameters & Results $(\% \mathbf{w} / \mathbf{w})$ \\
\hline 1 & Total ash value & 7.94 \\
2 & Acid-insoluble ash & 2.48 \\
3 & Water-soluble ash & 3.96 \\
4 & Moisture content & 7.7 \\
5 & Alcohol-soluble extractive & 10.75 \\
6 & Water-soluble extractive & 9.5 \\
7 & pH for 1\% solution & 6.89 \\
\hline
\end{tabular}

Table 2: Fluorescence analysis of root powder of Anthocephalus cadamba

\begin{tabular}{|c|c|c|c|}
\hline S. No. & Reagent & Daylight & UV light \\
\hline 1 & Drug powder as such & Pale brown & Bright yellow \\
\hline 2 & Conc. $\mathrm{H}_{2} \mathrm{SO}_{4}$ & Blackish-brown & Blackish-brown \\
\hline 3 & Dil. $\mathrm{H}_{2} \mathrm{SO}_{4}$ & Pale yellow & Yellow \\
\hline 4 & Conc. $\mathrm{HCl}$ & Dark brown & Dark brown \\
\hline 5 & Dil. $\mathrm{HCl}$ & Orangish-brown & Orangish-brown \\
\hline 6 & Conc. $\mathrm{HNO}_{3}$ & Muddy brown & Light brown \\
\hline 7 & Dil. $\mathrm{HNO}_{3}$ & Pale brown & Yellow \\
\hline 8 & Methanol & Pale brown & Bright yellow \\
\hline 9 & Chloroform & Cream color & Yellow \\
\hline 10 & Petroleum ether & Cream color & Yellow \\
\hline 11 & $10 \%$ Ferric chloride & Light brown & Greenish-yellow \\
\hline 12 & $10 \% \mathrm{NaOH}$ & Orangish-brown & Brown \\
\hline 13 & Ammonia solution & Pale brown & Yellow \\
\hline 14 & $\mathrm{CH}_{3} \mathrm{COOH}$ & Light brown & Bright brown \\
\hline 15 & Distilled water & Pale brown & Yellow \\
\hline
\end{tabular}

UV: Ultraviolet

Table 3: Preliminary phytochemical screening of petroleum ether and ethanol extracts of roots of Anthocephalus cadamba

\begin{tabular}{llll}
\hline S. No. & Phytoconstituents & \multicolumn{2}{l}{$\begin{array}{l}\text { Extracts of the root of } \\
\text { Anthocephalus cadamba }\end{array}$} \\
\cline { 3 - 4 } & & $\begin{array}{l}\text { Petroleum } \\
\text { ether extract }\end{array}$ & $\begin{array}{l}\text { Ethanol } \\
\text { extract }\end{array}$ \\
\hline 1 & Alkaloids & $-\mathrm{ve}$ & $+\mathrm{ve}$ \\
2 & Proteins and amino & $-\mathrm{ve}$ & $-\mathrm{ve}$ \\
& acids & & \\
3 & Saponins & $-\mathrm{ve}$ & $+\mathrm{ve}$ \\
4 & Phenols & $-\mathrm{ve}$ & $+\mathrm{ve}$ \\
5 & Flavonoids & $-\mathrm{ve}$ & $+\mathrm{ve}$ \\
6 & Glycosides & $-\mathrm{ve}$ & $+\mathrm{ve}$ \\
7 & Steroids & $+\mathrm{ve}$ & $+\mathrm{ve}$ \\
8 & Tannins & $-\mathrm{ve}$ & $+\mathrm{ve}$ \\
9 & Terpenoids & $-\mathrm{ve}$ & $+\mathrm{ve}$ \\
10 & Fats and oils & $+\mathrm{ve}$ & $-\mathrm{ve}$ \\
\hline
\end{tabular}

+ve - indicates the presence of phytoconstituents, -ve - indicates the absence of phytoconstituents

quality assessment of medicinal plants is ensuring the authenticity of the desired species for intended use [17]. It is conducted by various techniques such as macro- and micro-scopic identification, physicochemical analysis, and fluorescence studies. Observation of morphology and microscopic features is a major aid in the identification of raw materials. The observation of cellular level morphology of these roots helps in quality control profiling. These characteristic profiling mainly play a key role in identification of powdered drugs, since in these cases, many of the diagnostic characters lost. Physicochemical evaluation serves as valuable source of information and helps in judging the purity and quality of drugs [18]. Ash values determined in our study were especially helpful to find out the existence of any foreign inorganic matter such as metallic salts and silica [19]. Extraction values are primarily 
Table 4: High-performance thin-layer chromatography profile of the ethanol extract of roots of Anthocephalus cadamba

\begin{tabular}{|c|c|c|c|c|c|c|c|c|c|}
\hline Peak & Start Rf & Start height & Maximum Rf & Maximum height & Maximum (\%) & End Rf & End height & Area & Area (\%) \\
\hline 1 & -0.03 & 179.6 & -0.03 & 180.7 & 43.19 & -0.01 & 0.0 & 782.8 & 10.68 \\
\hline 2 & 0.01 & 0.3 & 0.03 & 13.9 & 3.33 & 0.05 & 2.3 & 193.7 & 2.64 \\
\hline 3 & 0.05 & 2.5 & 0.07 & 10.7 & 2.55 & 0.09 & 0.8 & 157.4 & 2.15 \\
\hline 4 & 0.17 & 1.3 & 0.23 & 51.5 & 12.32 & 0.27 & 0.2 & 1439.4 & 19.64 \\
\hline 5 & 0.35 & 2.2 & 0.41 & 123.7 & 29.57 & 0.47 & 0.9 & 3706.6 & 50.58 \\
\hline 6 & 0.60 & 2.5 & 0.65 & 26.9 & 6.42 & 0.70 & 5.0 & 835.6 & 11.40 \\
\hline 7 & 0.70 & 5.1 & 0.72 & 11.0 & 2.63 & 0.75 & 0.5 & 212.0 & 2.89 \\
\hline
\end{tabular}

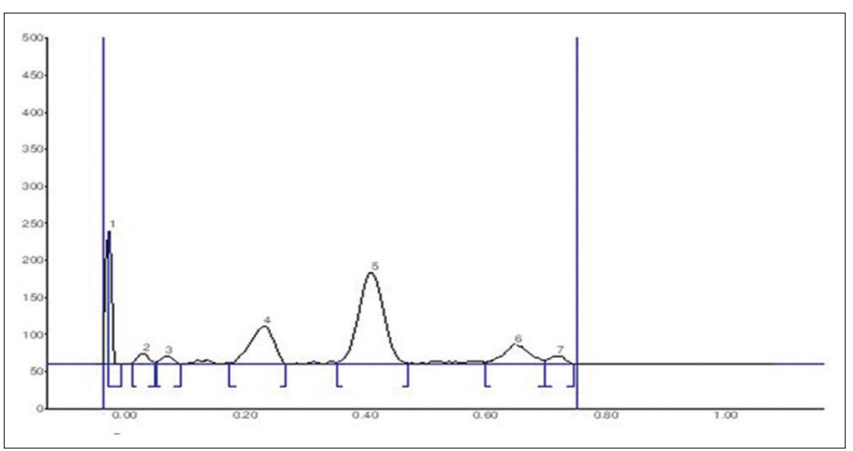

Fig. 4: HPTLC chromatograph of thee ethanol extract of roots of A. cadamba

useful for the determination of exhausted or adulterated drug and it provides an idea about the estimation of specific constituents soluble in that particular solvent used for the extraction [20]. In our current findings, the alcohol extractive value found to be higher than water. This inference that phytoconstituents present in the extracts may be more soluble in alcohol than water.

The moisture content determination indicates the storage capacity of crude drug as the moisture is responsible for its decomposition due to microbial attack or chemical changes [18]. In the present study, the moisture content of our roots is low; therefore, they can be stored without microbial attack. Fluorescence study is another essential parameter for the first-line standardization of crude drug and in identification of adulterants [21]. Phytochemical screening of the plant material is essential to predict the pharmacological activities of the plant materials [22]. The preliminary phytochemical screening revealed the presence of various bioactive phytoconstituents which were immensely beneficial for assessing the pharmacological activity of these roots.

HPTLC is a sophisticated, conventional analytical approach for standardization [23]. "HPTLC fingerprint profile is an important powerful procedure for the determination of bioactive compounds in herbal medicine and found to be a linear, precise, and accurate method for herbal identification and can be used further for authentication and standardization of the medicinally important plants" [24]. The present HPTLC fingerprint analysis showed that there was more number of peaks when the solvent extract was scanned at $366 \mathrm{~nm}$ and $254 \mathrm{~nm}$. The variations in number of peaks and $\mathrm{R}_{\mathrm{f}}$ values evidence qualitative variation of the different phytochemical constituents present in the root extract. The developed fingerprint aids in the differentiation of these roots from the adulterant and acts as biochemical marker in systematic studies of these roots.

\section{CONCLUSION}

The present findings revealed various characteristic features of the roots of A. cadamba which aids in differentiation of genuine drug from its adulterants. Thus, the current study provided the information with respect to identification and authentication of crude drug and served as a reference point for the proper identification of roots of this medicinal plant, thereby contributing to the scientific world of research.

\section{AUTHORS' CONTRIBUTIONS}

The experimental part of work and preparation of manuscript was done by the first author (Dr. K. Sai Sruthi). The guidance for experimental design and correction of manuscript was done by the second author (Prof. A. Sreedevi).

\section{CONFLICTS OF INTEREST}

No conflicts of interest.

\section{REFERENCES}

1. Shehla A, Uzma H, Jaffar A, Saiqa I. Pharmacognostic studies of stem, roots and leaves of Malva parviflora L. Asian Pac J Trop Biomed 2014;4:410-5.

2. Nayak BS, Patel KN. Pharmacognostic studies of the Jatropha curcas leaves. Int J Pharmtech Res 2010;2:140-3.

3. Kalidass C, Amish AD, Mohan VR. Pharmacognostic studies on Ichnocarpus frutscens. J Herb Med Toxicol 2009;3:9-15.

4. Atul D, Satish N, Goupale DC. Anthocephalus cadamba: A review. Pharmacogn J 2013;2:71-6.

5. WHO. Quality Control for Medicinal Plant Material. New Delhi: AITBS Publishers; 1998. p. 46-7.

6. Sass JE, Elements of Botanical Micro Technique. New York: MCgraw Hill Book Co.;1940. p. 222.

7. Brain KR, TurnerTD. The Practical Evaluation of Phytopharmaceuticals. Bristol: Wright Scientechnica; 1975. p. 4-9.

8. Johansen DA. Plant Microtechnique. $1^{\text {st }}$ ed. New York: Mc Graw Hill Book Co.; 1940. p. 182-203.

9. Esau K. Plant Anatomy. New York: John Wiley and Sons; 1964. p. 767.

10. O'Brien TP, Feder N, Mc Cull ME. Polychromatic staining of plant cell walls by toluidine blue-o. Protoplasma 1964;59:364-73.

11. Kokate CK. Practical Pharmacognosy. New Delhi: Vallabh Prakashan; 1994. p. 15-30.

12. Khandelwal A. Practical Pharmacognosy. $18^{\text {th }}$ ed. Pune: Nirali Prakashan; 2007.

13. The Ayurvedic Pharmacopeia of India. $1^{\text {st }}$ ed. Part 1. Vol. 3. New Delhi: Government of India Ministry of Health and Family Welfare Department of Indian Systems of Medicine and Homeopathy; 2007. p. 147.

14. Chase CR, Pratt RJ. Fluorescence of powdered vegetable drugs with particular reference to development of system of identification. J Am Pharm Assoc 1949;38:32-8.

15. Harbone JB. Phytochemical Methods. Londaon: Chapman and Hall Ltd,; 1973. p. 149-88.

16. Ali I, Rizwani GH, Shareef H, Khan S. Pharmacognostic studies of Dalbergia sisso Roxb. Int J Pharm Pharm Sci 2016;8:48-53.

17. Mallya R, Bhitre MJ. Pharmacognostic standardisation and chromatographic fingerprinting of leaves and fruits of Zanthoxylum rhetsa. Int J Pharm Pharm Sci 2018;10:101-4.

18. Isaac K, Abraham Y, Antonia O, Lincoln K, Jato J. Pharmacognostic standardization of Hilleria latifolia. Asian Pac J Trop Med 2014;4:941-5.

19. Nishi R, Radha M. Pharmacognostic and physicochemical analysis on the leaves of Brufeslsia americana L. Asian Pac J Trop Biomed 2012;2:s305-7

20. Shashi A, Sanjay K, Amita V, Mayank K. Pharamcognostic and phytochemical evaluation of Dolichos biflorus. Asian Pac J Trop Dis 2014;4:97-101.

21. Kadam PV, Yadav KN, Narappanawar NS, Shivatare RS, Patil MJ. 
Pharmacognostic and phytochemical studies on roots of Agave americana (Agavaceae). Int J Pharm Phytochem Res 2012;4:92-6.

22. Sreedevi A, Bharathi K, Prasad, KVSRG. Effect of decoction of root bark of Berberis aristata on cisplatin-induced nephrotoxicity in rats. Int J Pharm Pharm Sci 2010;2:51-6.

23. Shivatare RS, Nagore DH, Nipanikar SU. 'HPTLC' an important tool in standardization of herbal medical product: A review. J Sci Innov Res 2013;2:1086-96

24. Mohammed MS, Alajmi MF, Alam P, Khalid HS, Mahmoud AM, Ahmed WJ. Chromatographic fingerprint analysis of anti-inflammatory active extract fractions of aerial parts of Tribulus terrestris by HPTLC technique. Asian Pac J Trop Biomed 2014;4:203-8. 